\title{
Extradural Spinal Arachnoid Cyst Occurring in a Child: A Case Report
}

\section{Bir Çocukta Oluşan Ekstradural Spinal Araknoid Kist: Bir Olgu Sunumu}

\author{
Souad BAKHTI ${ }^{1}$, Lila DJAADI ${ }^{1}$, Fella TERKMANI ${ }^{2}$, Nabila TIGHILT ${ }^{1}$, Mohamed DJENNAS $^{1}$ \\ ${ }_{1}^{1}$ Academic Hospital Mustapha Pacha, Pediatric Unit of Neurosurgery Department, Algiers, Algeria \\ ${ }^{2}$ Academic Hospital Mustapha Pacha, Department of Pathology, Algiers, Algeria
}

Corresponding Author: Souad BAKHTI / E-mail: bak-sou@hotmail.com

\begin{abstract}
Extradural archnoid spinal cysts are rare lesions. Their localization is usually the thoracic spine. Clinically, they are a cause of spinal cord and/ or nerve roots compression. The diagnosis is made by magnetic resonance imaging (MRI). The pathophysiology is not well known and seems to be different from intradural lesions. The best treatment is surgery. We report the case of a 5-year-old girl with spinal cord compression symptoms who was treated by open surgery. We performed dural defect repair. The outcome was good in the immediate post operative period without complication and total recovery.
\end{abstract}

KEYWORDS: Arachnoid cyst, Spine, Extradural, Dural defect repair, Child

öz

Ekstradural araknoid spinal kistler nadir lezyonlardır. Lokalizasyonları genellikle torasik omurgadır. Klinik olarak, omurilik ve/veya sinir kökü kompresyonunun bir nedenidirler. Tanı manyetik rezonans görüntüleme (MRG) ile konur. Patofizyoloji iyi bilinmemektedir ama intradural lezyonlardan farklı gibidir. En iyi tedavi cerrahidir. Açık cerrahiyle tedavi edilen ve omurilik kompresyonu belirtileri olan 5 yaşında bir kızı sunuyoruz. Dural defekt tamiri gerçekleştirdik. Sonuç erken postoperatif dönemde iyiydi ve komplikasyon görülmeyip tam iyileşme oluştu.

ANAHTAR SÖZCÜKLER: Araknoid kist, Omurga, Ekstradural, Dural defekt tamiri, Çocuk

\section{INTRODUCTION}

Spinal extradural arachnoid cysts are rare lesions that are generally localized in the middle and lower thoracic region $(1,2,3,6,9)$. When they are symptomatic, they cause compression of the spinal and/or nerve roots. Surgery is indicated in symptomatic cases. Outcome is generally good. In this report we present the case of a 5-year-old with a symptomatic extradural spinal arachnoid cyst of the upper and middle thoracic spine treated successfully by surgery.

\section{CASE REPORT}

This 5-year-old girl presented with a 2-month history of dorsal pain followed by difficulties in walking. No history of trauma or surgery was reported.

Neurological examination revealed flasco-spasmodic paraparesis and bowel dysfunction. Hyperactivity of deep tendons was noted at the lower extremities. Babinski sign was present bilaterally. Muscle tonus at the lower extremities was increased. MRI revealed an extradural cystic lesion extending from T2 to T6 vertebral bodies located posteriorly, compressing the spinal cord (Figure $1 \mathrm{~A}-\mathrm{C}$ ). The lesion had the intensity of CSF on T1- and T2-weighted images. There was no contrast enhancement.
We performed a laminotomy from the T1 to T6 level. We found an extradural cystic lesion full of fluid resembling CSF and the walls of the cyst were thin. The cyst was in contact with the dura through a small defect at the posterior aspect of the spinal cord. The cord was compressed. There was no adherence to the dura. The cyst was opened and its walls excised. The spinal cord appeared well vascularized (Figure 2A-C). The lesion was only extradural. The defect was repaired with watertight sutures without duraplasty. Sutures were not under tension. Samples of the cyst wall were examined by the pathologist who diagnosed an arachnoid cyst (Figure 3).

There was no complication and total recovery was obtained at 3 months. Control MRI obtained at 6 months post operatively showed no compression of the spinal cord (Figure 4A,B).

\section{DISCUSSION}

Extradural arachnoid cysts are rare lesions. The pathogenesis is not well known but is different from intradural cysts (6). Several mechanisms are probably involved $(3,4)$. These lesions seem to be associated with trauma, surgery and frequently with congenital anomalies (5). In our case there was no history of trauma or surgery so we can conclude that it was a consequence of a congenital anomaly. Generally these lesions are located most frequently in the thoracic 

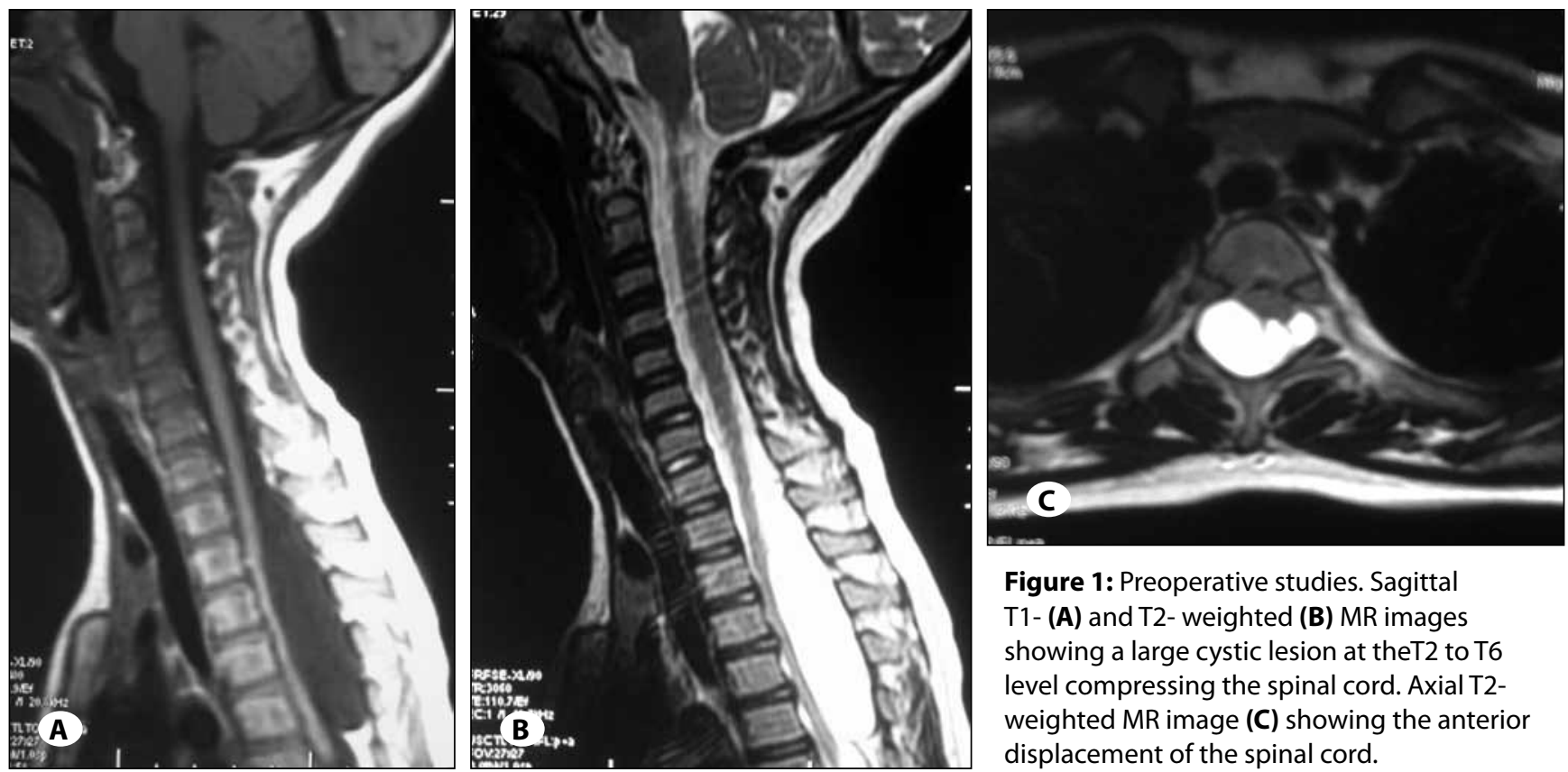

Figure 1: Preoperative studies. Sagittal T1- (A) and T2- weighted (B) MR images showing a large cystic lesion at theT2 to T6 level compressing the spinal cord. Axial T2weighted MR image (C) showing the anterior displacement of the spinal cord.
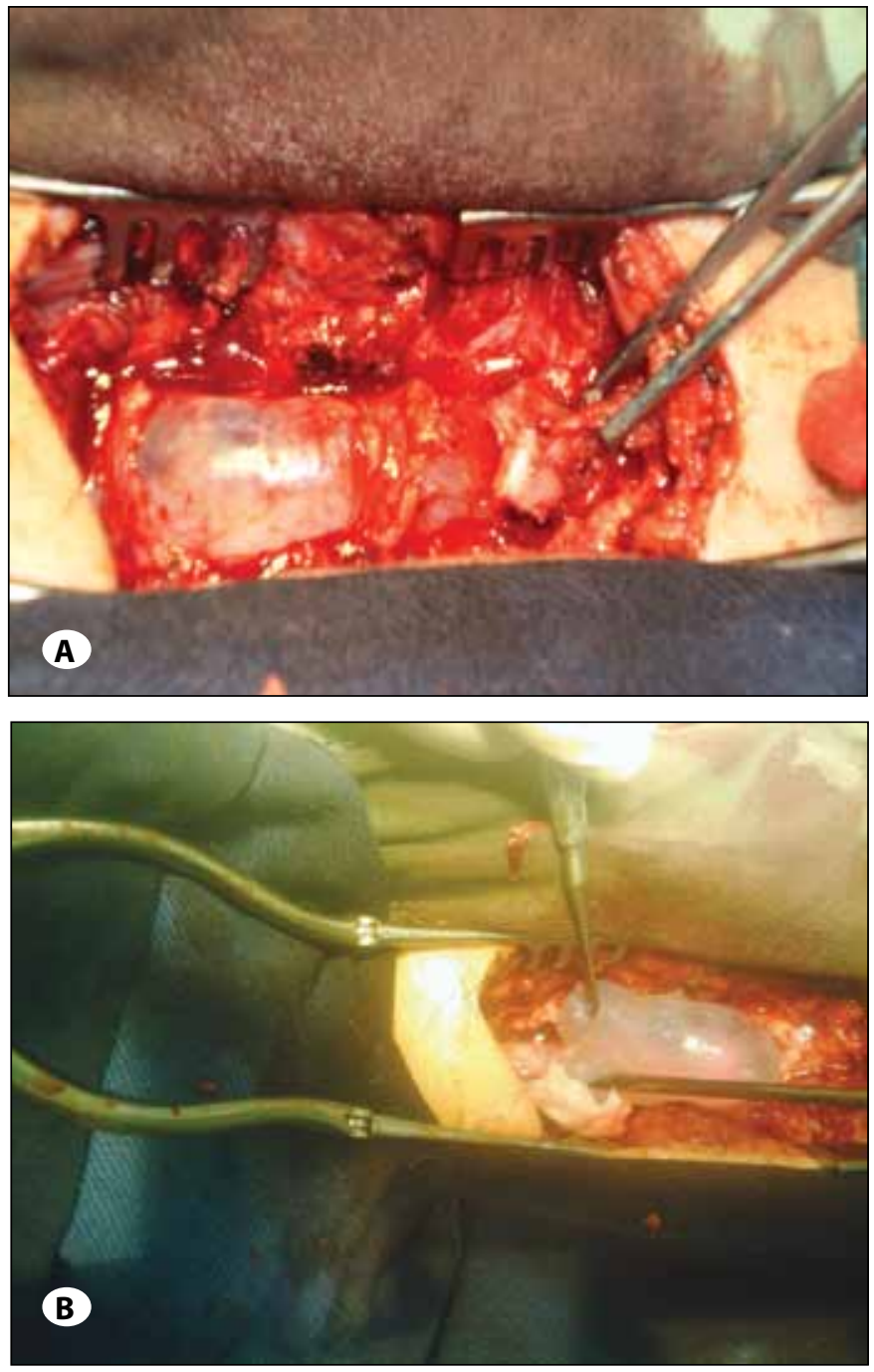

Figure 2: Operative images. A) the cyst appears just under the vertebral lamina. B) mobilization of the cyst to reach the dural defect. C) the cyst's wall after rupture and the spinal cord appear well vascularized through the dural defect that was enlarged to inspect the spinal cord.

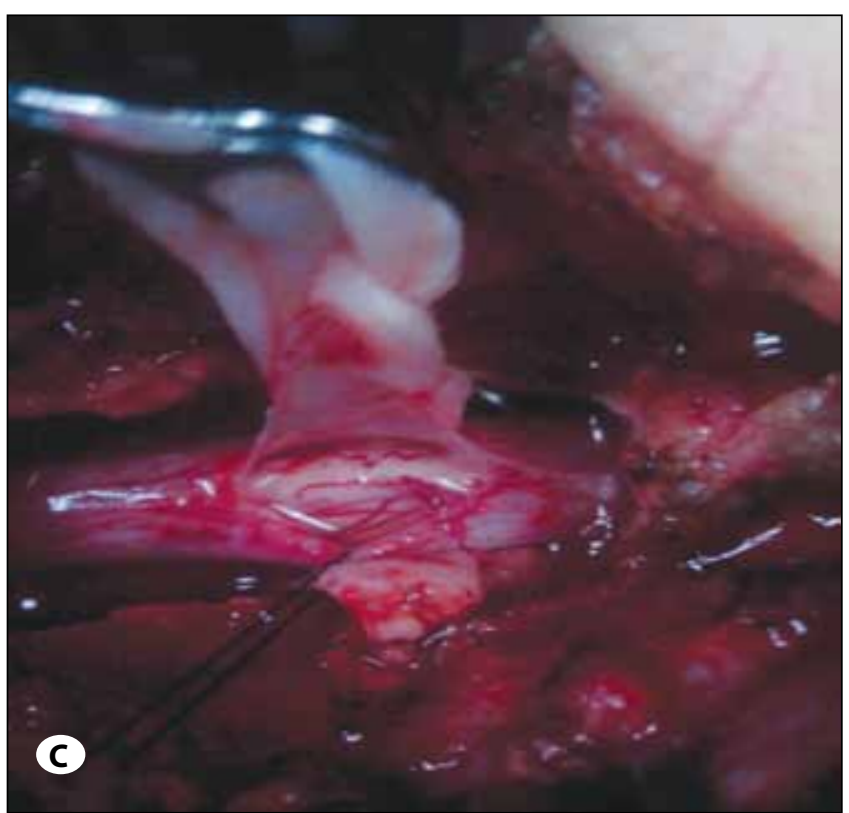


spine with $65 \%$ of the cases (1) and mostly at the middle and lower thoracic region of the spine $(1,2,3,6,9)$. Our lesion was located in the upper and middle thoracic spine. In the majority of cases that are not caused by trauma or surgery there is a congenital dural defect which permit the herniation of the arachnoid membrane in the extradural space $(2,5$, $6,10)$. The defect may be congenital or acquired (2). In our case, since there was no history of trauma or surgery we can conclude that the defect was congenital. Arachnoid cysts are sometimes asymptomatic and can enlarge and produce symptoms. Mechanisms of growth for these cysts are not well

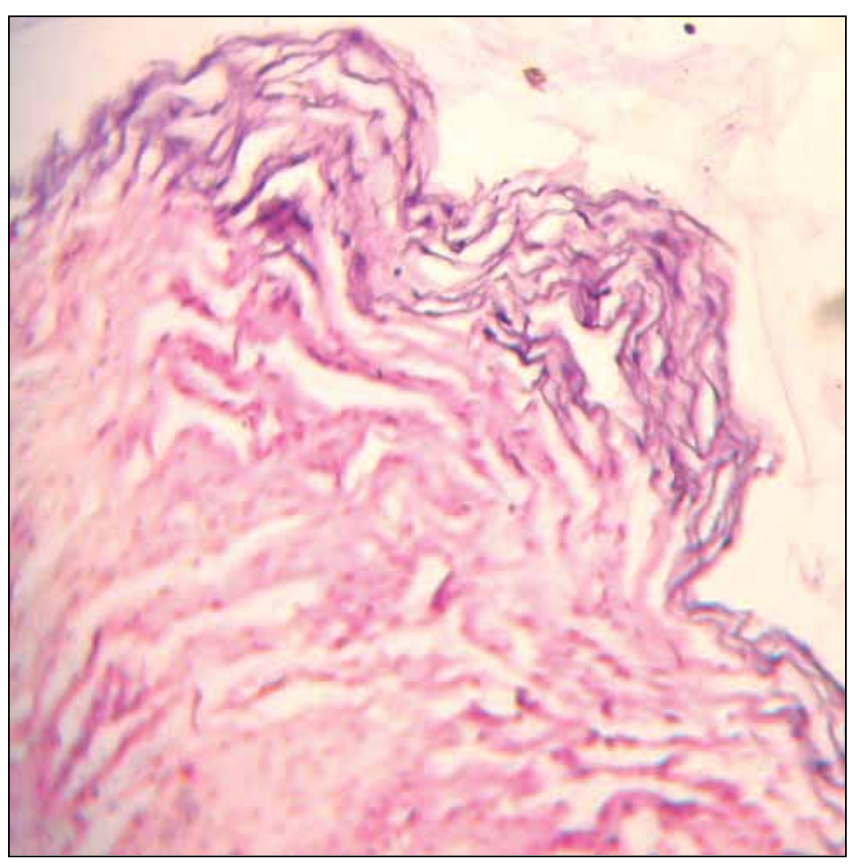

Figure 3: Tissue section demonstrating arachnoid cells of the cyst wall. Original magnification x40. known. It may be pulsatile CSF dynamics, ball-flap mechanism or osmotic gradient $(3,11)$. Clinically these lesions are a cause of spinal cord compression and/or nerve roots. The severity of symptoms depends of the location and the size. In our case there was only a compression of the spinal cord with paraparesis and bladder dysfunction. The better tool for the diagnosis is MRI as it can show the exact localization, the size and the degree of compression. This modality of imaging has great specificity; the lesions have the same intensity of the CSF on T1- and T2-weighted images and there is no contrast enhancement (9). Asymptomatic patients or those with mild symptoms can be managed by clinical and imaging followup (2). In all other cases surgery is the best management. Several techniques have been proposed: fenestration of the cyst, resection of the cyst's wall, aspiration or placement of a shunt to the pleural, peritoneal and subarachnoid spaces $(3,6,8,10)$. Some authors report failure with placement of a shunt (6). Simple aspiration is also not recommended (2). It seems that the best definitive treatment is resection of the walls of the cyst with repair of the dural defect because this later prevent cyst refilling $(1,3,4,5,6,9,10)$. In some instances, the complete resection of the walls cannot be achieved because they are adherent to the spinal cord or to the dura and then only the resection of the posterior wall of the cyst must be done $(4,7)$. It seems that no recurrence will occur by leaving a small part of the cyst walls $(6,7,11)$. Sometimes an extensive duraplasty is needed to close the defect (7). Our patient was treated by the total resection of the cyst walls as there were no adherences to the dura and the defect was closed without duraplasty. There is debate on the access to the lesion: should we perform a laminotomy or a laminectomy? Some authors argue that a laminotomy should be done to avoid postoperative kyphosis (2). However, there is no evidence that laminotomy is superior to laminectomy (1). We have performed a laminotomy in our case since it was a child. Post operative recovery is generally obtained $(1,4,5,6$,
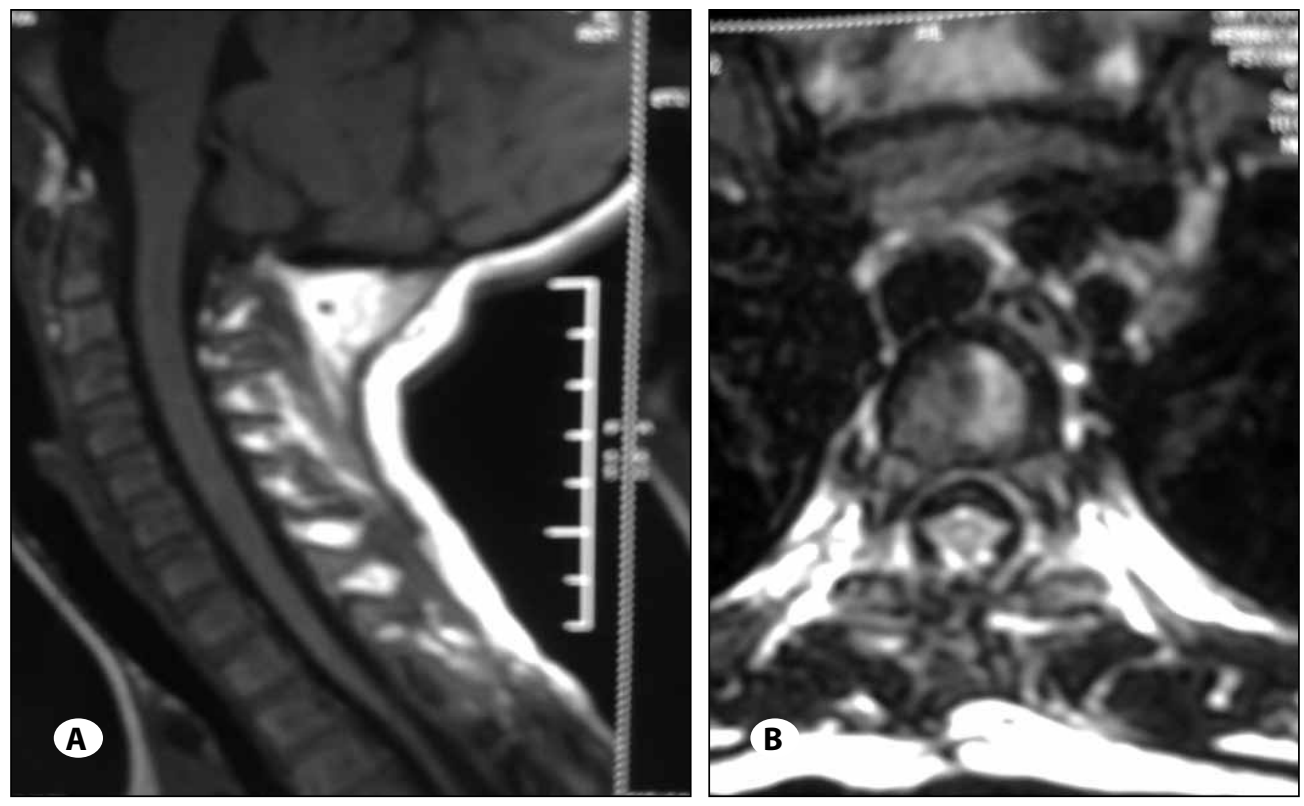

Figure 4: Postoperative images obtained at 06 months. Sagittal T1-weighted MR image showing no recurrence of the lesion (A). Axial T1-weighted MR image demonstrating the disappearance of the anterior displacement of the spinal cord (B). 
$7,11)$ but not in all cases. In fact the recovery depends mainly on the degree and the duration of the compression $(3,6)$. In our case the good recovery was predicted by the age, the short duration of the symptoms ( 2 months) and the operative findings (spinal cord well vascularized and pulsations after decompression).

\section{CONCLUSION}

Extradural spinal arachnoid cysts are infrequent lesions with few cases reported in the literature. Surgery is indicated for symptomatic cases. The best surgical management is laminotomy or laminectomy, total resection of the cyst's walls if possible, and closure of the dural defect if present to avoid refilling of the lesion. Recovery seems mainly in relation with the duration of symptoms, so early diagnosis must be emphasized.

\section{REFERENCES}

1. Bitaraf MA, Zeinalizadeh M, Meybodi AT, Meybodi KT, Habibi Z: Multiple extradural spinal arachnoid cysts: A case report and review of the literature. Cases Journal 2: 7531, 2009

2. Ergun E, Borcek AO, Cemil B, Dogulu F, Baykaner MK: Should we operate all extradural spinal arachnoid cysts? Report of a Case. Turk Neurosurg 18(1): 52-55, 2008

3. Hamamcioglu MK, Kilincer C, Hicdonmez T, Simsek O, Birgili B, Cobanoglu S: Giant cervicothoracic extradural arachnoid cyst: case report. Eur Spine J 15 (Suppl 5):S595-S598, 2006
4. Hatashita S, Kondo A, Shimizu T, Kurosu A, Ueno H: Spinal extradural arachnoid cyst: Case report. Neurol Med Chir (Tokyo) 41:318-321, 2001

5. Hernández-León O, Pérez-Nogueira YFR, Corrales N: Quiste aracnoideo espinal epidural postraumático: Presentación de un caso. Neurocirugía 22: 267-270, 2001

6. Kahraman S, Anik I, Gocmen S, Sirin S: Extradural giant multiloculated arachnoid cyst causing spinal cord compression in a child. J Spinal Cord Med 31:306-308, 2008

7. Kikuta KI, Hojo M, Gomi M, Hashimoto N, Nozaki K: Expansive duraplasty for the treatment of spinal extradural arachnoid cysts. J Neurosurg Spine 4:251-255, 2006

8. Kumar K, Malik S, Schulte PA: Symptomatic spinal arachnoid cysts: Report of two cases with review of the literature. Spine 28: 25-29, 2003

9. Netra R, Min L, Shao Hui M, Wang JC, Bin Y, Ming Z: Spinal extradural meningeal cysts: An MRI evaluation of a case series and literature review. J Spinal Disord Tech 24(2):132-136, 2011

10. Payer M, Brühlhart K: Spinal extra dural arachnoid cyst: Review of surgical techniques. J Clin Neurosci 18(4):559-560, 2011

11. Uemura $K$, Yoshizawa $T$, Matsumura MA, Asakawa $H$, Nakamagoe K, Nose T: Spinal extradural meningeal cyst. Case report. J Neurosurg 85:354-356, 1996 